\title{
HUBUNGAN TINGKAT PENGETAHUAN IBU MELAHIRKAN DENGAN PEMBERIAN MP-ASI DI BAGIAN OBSTETRI DAN GINEKOLOGI BLU RSU PROF. DR. R. D. KANDOU MANADO
}

\author{
${ }^{1}$ Yoslianto Sarampang \\ ${ }^{2}$ Freddy W. Wagey \\ ${ }^{2}$ Maria F. Loho
}

\author{
${ }^{1}$ Kandidat Skripsi Fakultas Kedokteran Universitas Sam Ratulangi Manado \\ ${ }^{2}$ Bagian Obstetri dan Ginekologi RSUP Prof. DR. R. D. Kandou Manado \\ Email: yoslinara@gmail.com
}

\begin{abstract}
Most mothers now breastfeed less than 6 months and more gave extra food at that age but when viewed in terms of nutritional content of breast milk is superior to the other foods that have a lot of risks that can be caused to the health of the baby. Method: This research used a descriptive analytic cross-sectional study (cross-sectional) located in the obstetrics and gynecology section childbirth Prof. Dr. R. D. Kandou General Hospital Malalayang Manado in November 2012. Result: Based on the statistical test using the chi square test $(p<0.05)$ in this study was $p=0.031(p<0.05)$. Thus it is said that there is a significant relationship between the level of knowledge of mothers giving birth to the complementary feeding. Conclusion: In terms of education are mostly good (high school) we can say that there is no relationship with the mother despite knowledge of the test results obtained statistically significant value. It can be seen from the findings that most mothers who have given birth (72\%) turned out to have given formula milk shortly after birth.
\end{abstract}

Keywords: Knowledge, Childbirth, Complementary Feeding.

\begin{abstract}
Abstrak: Kebanyakan ibu sekarang memberikan ASI tidak sampai 6 bulan dan lebih memberikan makanan tambahan pada usia tersebut padahal bila dilihat dari segi kandungan nutrisi ASI lebih unggul dari makanan pendamping yang lain sehingga memiliki banyak resiko yang bisa di timbulkan terhadap kesehatan bayi. Metode: Penelitian ini menggunakan desain penelitian deskriptif analitik dengan studi potong lintang (cross sectional) yang berlokasi di ruang nifas bagian obstetri dan ginekologi RSU Prof. Dr. R. D. Kandou Malalayang Manado bulan November 2012. Hasil: Berdasarkan uji statistik dengan menggunakan uji chi square $(p<0,05)$ pada penelitian ini adalah $p=0,031(p<0,05)$. Dengan demikian dikatakan bahwa terdapat hubungan yang bermakna antara tingkat pengetahuan ibu melahirkan dengan pemberian MP-ASI. Simpulan: Dilihat dari segi pendidikan yang kebanyakan adalah baik (SLTA) dapat dikatakan bahwa tidak ada hubungan dengan pengetahuan ibu meskipun dari hasil uji statistik diperoleh nilai yang bermakna. Hal tersebut dapat dilihat dari hasil penelitian bahwa kebanyakan ibu yang telah melahirkan (72\%) ternyata telah memberikan susu formula sesaat setelah lahir.
\end{abstract}

Kata kunci: Pengetahuan, Melahirkan, MP-ASI (Makanan Pendamping ASI).

Pemberian ASI dimulai dari bayi baru lahir sampai pada usia 6 bulan atau yang sering dikenal ASI Eksklusif dimana diberikan hanya dari air susu ibu saja tanpa memberikan makanan/minuman tambahan termasuk air putih atau susu formula dan setelah diberikan selama 6 bulan barulah diberikan makanan pendamping ASI (disingkat MP-ASI) yang sesuai dengan perkembangan anak. ${ }^{1-3}$ 
Namun kebanyakan ibu memberikan ASI tidak sampai 6 bulan padahal bila dilihat dari segi kandungan nutrisi ASI lebih unggul dari makanan pendamping yang lain sehingga memiliki banyak resiko yang bisa di timbulkan terhadap bayi. ${ }^{4}$ Menurut data Riskesdas tahun 2007, Kematian bayi terbanyak karena diare (42 \%) dan pneumonia (24 \%), penyebab kematian balita disebabkan diare (25,2 \%), pneumonia (15,5 \%) dan DBD (6,8 \%).

Ada banyak kendala yang dikeluhkan oleh ibu seperti puting susu yang lecet, produksi asi yang kurang, faktor psikologi dari ibu yang disebabkan karena stress atau khawatir juga kurangnya pengetahuan dari ibu juga menjadi faktor tidak di berikannya ASI eksklusif. ${ }^{6}$ Menurut hasil Survei Demografi dan Kesehatan Indonesia (SDKI) tahun 2006-2007, data jumlah pemberian ASI eksklusif pada bayi di bawah usia dua bulan hanya mencakup $67 \%$ dari total bayi yang ada. Persentase tersebut menurun seiring dengan bertambahnya usia bayi. Yakni, 54\% pada bayi usia 2-3 bulan dan 19\% pada bayi usia 7-9. Yang lebih memprihatinkan, $13 \%$ bayi di bawah dua bulan telah diberi susu formula dan satu dari tiga bayi usia 2-3 bulan telah diberi makanan tambahan. ${ }^{7}$

Berdasarkan latar belakang di atas maka peneliti tertarik untuk melakukan penelitian tentang hubungan tingkat pengetahuan ibu melahirkan dengan pemberian makanan pendamping ASI di RSU. Prof. Dr. R.D. Kandou Malalayang, Manado bulan November 2012.

\section{Rumusan Masalah}

Berdasarkan latar belakang di atas maka yang menjadi permasalahan dalam penelitian ini adalah "Apakah ada hubungan tingkat pengetahuan ibu melahirkan dengan pemberian MP-ASI?”

\section{Tujuan Penelitian}

\section{Tujuan Umum}

Mengetahui hubungan tingkat pengetahuan pada ibu melahirkan dengan pemberian MP-ASI.

\section{Tujuan Khusus}

1. Untuk mengetahui tingkat pengetahuan ibu terhadap MP-ASI

2. Untuk mengetahui tindakan ibu terhadap pemberian MP-ASI.

\section{Manfaat Penelitian}

Dapat memberikan sumbangan dalam perkembangan ilmu pengetahuan yang berhubungan dengan pemberian makanan pendamping ASI yang baik dan benar, dapat memberikan penyuluhan/ informasi kepada ibu mengenai pemberian makanan pendamping ASI yang tepat setelah usia 6 bulan, untuk menambah dan memperkaya wawasan dan pengetahuan terutama tentang pemberian makanan pendamping ASI, dapat digunakan sebagai bahan penelitian selanjutnya.

\section{METODE PENELITIAN}

Penelitian ini menggunakan desain penelitian deskriptif analitik dengan studi potong lintang (cross sectional). Penelitian ini akan dilakukan pada bulan November 2012 yang berlokasi atau bertempat di ruang nifas bagian obstetri dan ginekologi RSU. Prof. Dr. R.D. Kandou Malalayang, Manado. Dengan populasinya adalah seluruh ibu melahirkan dan menyusui yang dirawat di ruang nifas bagian obstetri dan ginekologi RSU. Prof. Dr. R.D. Kandou Malalayang, Manado. Sampelnya adalah ibu melahirkan dan menyusui dengan pengambilan sampel secara simple random sampling. Seluruh sampel adalah populasi dan terdapat 50 yang terpilih menjadi sampel.

Pada penelitian ini menggunakan data primer yaitu kuesioner. Pengukuran kuesioner menggunakan skala Guttman dimana jawaban Positif adalah bernilai 1 dan jawaban Negatif adalah bernilai 0.Data yang diperoleh akan di kumpulkan dan di olah, baik secara manual maupun dengan menggunakan komputer kemudian akan di tampilkan atau disajikan dalam bentuk tabel distribusi frekuensi serta 
menggunakan program SPSS versi 17 untuk analisis data.

\section{HASIL PENELITIAN}

\section{Karakteristik Responden}

Berdasarkan hasil penelitian, diperoleh bahwa umur 20-35 tahun menjadi umur terbanyak dengan 28 orang (56\%), diikuti umur >35 tahun dengan 12 orang (24\%) dan yang umur $<20$ tahun menjadi umur yang paling sedikit/terendah jumlahnya dengan 10 orang (20\%). Dari hasil penelitian ini didapatkan bahwa pendidikan terakhir dari responden yang terbanyak adalah pendidikan SLTA sebanyak 31 orang (62\%), SLTP sebanyak 9 orang (18\%), kemudian SD dan PT berjumlah sama sebanyak 4 orang (8\%), Akademik/D3 sebanyak 2 orang (4\%). Pada hasil penelitian diperoleh, di mana kebanyakan responden memilih Tidak bekerja sebanyak 23 orang (46\%) setelah melahirkan dan yang memilih bekerja diluar rumah setelah melahirkan sebanyak 16 orang (32\%) dan sedikit dari responden memilih bekerja didalam rumah sebanyak 11 orang (22\%).

\section{Pengetahuan Ibu tentang MP-ASI}

Berdasarkan hasil penelitian tentang pengetahuan MP-ASI dapat dilihat, dimana sebanyak 42 responden (84\%) telah mengetahui tentang makanan pendamping ASI dan 8 responden (16\%) tidak mengetahui tentang makanan pendamping ASI. Pengetahuan tentang pengertian MPASI sebanyak 45 responden (90\%) menjawab dengan salah dan pada umur berapa sebaiknya diberikan makanan tambahan sebanyak 34 responden (68\%) menjawab dengan benar. Pengetahuan tentang jenis makanan yang pertama kali diberikan kepada bayi usia $>6$ bulan sebanyak 49 responden (98\%) menjawab benar serta yang merupakan makanan pendamping ASI sebanyak 50 responden (100\%) menjawab benar. Pengetahuan ibu tentang berapa kali/frekuensi makanan tambahan diberikan dalam sehari kepada bayi usia 6-8 bulan sebanyak 44 responden
(88\%) menjawab benar dan alasan bayi perlu diberi makanan tambahan kebanyakan 49 responden (98\%) menjawab benar dengan alasan yang tepat.

Pengetahuan ibu terhadap pengaruhnya pemberian makanan tambahan bayi sebelum 6 bulan terhadap kesehatan bayi 31 responden (62\%) kebanyakan telah mengetahuinya dan menjawab benar. Pengetahuan ibu tentang menunda pemberian makanan tambahan pada usia $<6$ bulan dapat mengurangi resiko alergi kebanyakan 44 responden (88\%) memilih jawaban salah atau tidak tahu dan pada usia berapa sebaiknya bayi berhenti untuk menyusui kebanyakan 34 responden (68\%) menjawab salah. Berdasarkan hasil data diatas maka dapat dikelompokkan menjadi 3 kategori tingkat pengetahuan, di mana masing-masing kategori tersebut dapat dilihat pada tabel 1 .

Tabel 1. Distribusi Responden berdasarkan Kategori Pengetahuan Ibu tentang MP-ASI di Bagian Obstetri dan Ginekologi BLU RSU Prof. R. D. Kandou Malalayang, Manado Tahun 2012.

\begin{tabular}{lcc}
\hline Pengetahuan MP-ASI & n & $\mathbf{\%}$ \\
\hline Baik & 5 & 10 \\
Cukup & 44 & 88 \\
Kurang & 1 & 2 \\
\hline \multicolumn{1}{c}{ Total } & 50 & 100 \\
\hline
\end{tabular}

\section{Pemberian MP-ASI}

Berdasarkan hasil penelitian maka dapat dilihat pemberian ASI saja sampai usia 6 bulan sebanyak 35 responden (70\%) menjawab Ya dan 15 responden (30\%) menjawab Tidak. Pemberian makanan tambahan pada bayi saat berumur 4 bulan sebanyak 33 responden (66\%) menjawab Ya dan 17 responden (34\%) menjawab Tidak. Pemberian makanan tambahan ketika usia $<6$ bulan sebanyak 34 responden (68\%) menjawab Tidak. Pemberian makanan tambahan pada usia $<6$ bulan jika bayi rewel dan menangis sebanyak 31 responden (62\%) menjawab 
Tidak. Pemberian susu formula pada anak usia $<6$ bulan sebanyak 27 responden (54\%) menjawab Tidak. Pemberian makanan tambahan pada usia $<6$ bulan agar anak lebih gemuk sebanyak 30 responden (60\%) memilih jawaban Ya.

Pemberian makanan lunak seperti bubur susu sebagai makanan tambahan pertama bayi usia $>6$ bulan sebanyak 46 responden (92\%) memilih jawaban Ya. Pemberian makanan tambahan seperti susu formula ketika masih memberikan ASI kebanyakan 31 responden (62\%) menjawab Tidak. Pemberian makanan tambahan 1-3 kali sehari pada bayi usia $>6$ bulan sebanyak 40 responden (80\%) menjawab Ya. Pemberian susu formula sesaat setelah bayi lahir kebanyakan 36 responden (72\%) memilih jawaban Ya.Berdasarkan hasil data diatas maka dapat dikelompokkan menjadi 3 kategori pemberian MP-ASI, di mana masing-masing kategori tersebut dapat dilihat pada Tabel 2.

\section{Hubungan Tingkat Pengetahuan Ibu Melahirkan dengan Pemberian MP-ASI berdasarkan hasil dari Uji Chi Square}

Uji chi square yang digunakan adalah memiliki suatu nilai value yaitu $p<0,05$ dimana jika nilai $p<0,05$ maka dikatakan adanya hubungan antar kedua variabel, sedangkan bila nilai $p>0,05$ maka dikatakan tidak ada hubungan antar kedua variabel. Variabel yang telah diuji dengan chi square berikut hasilnya dapat dilihat dibawah ini pada Tabel 3.

\section{PEMBAHASAN}

\section{Pengetahuan tentang MP-ASI}

Berdasarkan hasil penelitian diatas tentang pengetahuan MP-ASI dapat dilihat pada tabel 1, dimana sebanyak 42 responden (84\%) telah mengetahui tentang makanan pendamping ASI . Seperti yang diuraikan oleh Sri, bahwa pentingnya ibu mengetahui makanan pendamping ASI terutama pemberian dan kegunaannya karena dapat membantu proses tumbuh kembang bayi sesuai dengan nutrisi yang diberikan sehingga dapat mengurangi resiko penyakit pada bayi. ${ }^{9}$

Mengenai pengertian MP-ASI sebanyak 45 responden (90\%) telah memilih sebagai makanan pengganti ASI, makanan yang diberikan pada usia $<6$ bulan dan tidak tahu sama sekali. Hal ini tidak sesuai dengan pendapat Sri, bahwa makanan pendamping itu adalah makanan selain air susu ibu yang diberikan ketika sudah 6 bulan tanpa mengganti ASI,

Tabel 2. Distribusi Responden berdasarkan Kategori Pemberian MP-ASI di Bagian Obstetri dan Ginekologi BLU RSU Prof. R. D. Kandou Malalayang, Manado Tahun 2012.

\begin{tabular}{ccc}
\hline Pemberian MP-ASI & N & \% \\
\hline Baik & 8 & 16 \\
Cukup & 26 & 52 \\
Kurang & 16 & 32 \\
\hline Total & 50 & 100 \\
\hline
\end{tabular}

Tabel 3. Hasil Uji Chi Square

\begin{tabular}{|c|c|c|c|c|c|c|c|c|c|}
\hline \multirow{3}{*}{ Variabel } & \multicolumn{6}{|c|}{ Pemberian MP-ASI } & & & \multirow[b]{2}{*}{$p<0,05$} \\
\hline & \multicolumn{2}{|c|}{ Baik } & \multicolumn{2}{|c|}{ Cukup } & \multicolumn{2}{|c|}{ Kurang } & \multicolumn{2}{|c|}{ Total } & \\
\hline & $\mathrm{n}$ & $\%$ & $\mathrm{n}$ & $\%$ & $\mathrm{n}$ & $\%$ & $\mathrm{n}$ & $\%$ & \multirow{5}{*}{0,031} \\
\hline \multicolumn{9}{|c|}{ Pengetahuan } & \\
\hline Baik & 3 & 60 & 2 & 40 & 0 & 0 & 5 & 100 & \\
\hline Cukup & 5 & 11,4 & 24 & 54,6 & 15 & 34 & 44 & 100 & \\
\hline Kurang & 0 & 0 & 0 & 0 & 1 & 100 & 1 & 100 & \\
\hline
\end{tabular}


namun ASI tetap diberikan bersamaan meski volume pemberiannya sedikit demi sedikit. $^{9}$

Di samping itu, dijelaskan bahwa pemberian MP-ASI yang cocok di berikan pada umur bayi, sebanyak 34 responden (68\%) menjawab di atas 6 bulan. Hal ini sesuai dengan Pedoman pemberian MPASI Lokal Departemen Kesehatan RI tahun 2006, mengatakan bahwa pemberian yang cocok/tepat diberikannya bayi makanan pendamping ASI adalah saat berusia 6 bulan sampai 24 bulan. ${ }^{11}$ Jenis makanan yang pertama kali diberikan kepada bayi usia $>6$ bulan sebanyak 49 responden (98\%) menjawab makanan lunak. Dan bubur susu sebagai makanan pendamping ASI pilihan dari 50 responden (100\%). Ini sama dengan yang dijelaskan oleh Ronald bahwa jenis makanan yang diberikan pada bayi usia $>6$ bulan yaitu makanan lembek dan lunak seperti bubur susu dan nasi tim. ${ }^{8}$ Frekuensi makanan tambahan diberikan dalam sehari kepada bayi usia 68 bulan sebanyak 44 responden (88\%) menjawab 1-3 kali, ini sesuai dengan yang dijelaskan dalam penelitian Bahri bahwa frekuensi pemberian pada bayi usia 6-8 bulan adalah 1-2x/hari untuk makanan utama seperti bubur susu, nasi tim dan cemilan seperti biskuit adalah $1 \mathrm{x} /$ hari. $^{10}$

Pentingnya pemberian makanan tambahan pada usia $>6$ bulan adalah guna meningkatkan kubutuhan zat gizi bayi itu sendiri seiring dengan tumbuh kembang bayi di sesuaikan dengan pertambahan umurnya yang juga membutuhkan nutrisi lebih. Itulah alasan mengapa bayi perlu diberi makanan tambahan dan kebanyakan 49 responden (98\%) menjawab agar kebutuhan akan zat gizi bertambah sesuai dengan pertambahan umurnya.Sementara itu pengaruh terhadap pemberian makanan tambahan bayi sebelum 6 bulan terhadap kesehatan bayi, 31 responden (62\%) kebanyakan telah mengetahuinya dan menjawab anak akan jadi sering mencret karena pencernaannya terganggu. Hal ini disebabkan karena fungsi pencernaan bayi masih belum siap atau kesulitan untuk menerima makanan tambahan sehingga dapat menganggu proses dari percernaan bayi, salah satunya mencret(diare). Jika hal ini dibiarkan akan sangat berbahaya khususnya bagi kesehatan bayi karena bisa menyebabkan dehidrasi atau kekurangan cairan. ${ }^{1}$

Dengan menunda pemberian makanan tambahan pada usia $<6$ bulan maka dapat mengurangi resiko alergi dan kebanyakan 44 responden (88\%) menjawab tidak, mungkin(ragu-ragu) dan tidak tahu mengenai hal tersebut. Hal ini penting untuk diketahui oleh para ibu, Nur mengatakan bahwa alergi sendiri dapat sering terjadi pada anak usia $<6$ bulan terhadap pemberian makanan tambahan lebih awal yaitu susu formula. Hal ini dikarenakan dalam komposisi susu formula terdapat berbagai macam protein yang dapat merangsang terjadinya alergi sehingga sistem kekebalan tubuh akan melawan protein yang terdapat pada susu formula sehingga reaksi alergipun muncul dan dapat mengganggu semua organ tubuh terutama pencernaan, kulit dan pernafasan. ${ }^{1}$

Dari hasil penelitian, menunjukkan bahwa kebanyakan 34 responden (68\%) mengatakan sebaiknya bayi berhenti untuk menyusui pada usia $<12$ bulan, $>12$ bulan dan $<24$ bulan. Padahal menurut Bahri dalam penelitiannya dikatakan, bayi sebaiknya berhenti menyusui hendaknya dimulai pada masa anak - anak berusia diatas 2 tahun. ${ }^{10}$ Karena kebutuhan nutrisi bayi ketika usia diatas 2 tahun semakin meningkat jadi tidak mungkin hanya ASI saja yang terus diberikan jadi perlu nutrisi tambahan yaitu MP-ASI yang diberikan pada usia tersebut menyesuaikan dengan usia bayi dan tumbuh kembangnya.

\section{Pemberian MP-ASI}

Berdasarkan hasil penelitian pada tabel 2 diatas maka didapatkan bahwa sebanyak 35 responden (70\%) tidak memberikan ASI saja sampai pada usia 6 bulan dan hanya 15 responden (30\%) yang memberikannya. Menurut data WHO di katakan bahwa hendaknya ibu memberikan ASI sampai pada usia 6 bulan kemudian nanti setelah 6 
bulan ASI di lanjutkan dengan pemberian makanan tambahan sampai usia 2 tahun atau lebih. ${ }^{3}$ Pada hasil penelitian diperoleh data pemberian makanan tambahan pada bayi saat berumur 4 bulan sebanyak 33 responden (66\%) menjawab Ya dan 17 responden (34\%) menjawab Tidak. Dulunya di tetapkan pemberian MP-ASI adalah saat usia 4 bulan tapi karena berbagai pertimbangan dunia kesehatan khususnya untuk kesehatan bayi maka bersama dengan WHO memutuskan untuk pemberian MP-ASI adalah setelah 6 bulan.

Hasil penelitian menunjukkan bahwa 34 responden (68\%), tidak memberikan makanan tambahan pada bayi ketika usia < 6 bulan, ini dibuktikan bahwa sangatlah penting pengetahuan ibu tentang MP-ASI itu seperti apa, karena itu akan menjadi keuntungan bagi kesehatan bayi nantinya.Dari hasil penelitian diperoleh hasil yang baik kalau sebanyak 31 responden (62\%) ternyata tidak memberikan makanan tambahan pada usia $<6$ bulan jika bayi rewel dan menangis.Jika bayi masih terus menangis karena kelaparan maka, ibu tidak perlu kuatir dengan jumlah produksi ASI-nya atau merasa kelelahan memberi ASI terusmenerus, cukup berikan air putih secukupnya di dalam botol dan biarkan bayi menikmatinya. Hal ini dibuktikan bahwa proses pencernaan bayi yang bagus dan cepat membuat bayi yang meminum ASI lebih sering merasa lapar ketimbang peminum susu formula. ${ }^{9}$

Hasil penelitian menunjukkan bahwa sebanyak 27 responden (54\%) ternyata tidak memberikan susu formula pada anak usia $<6$ bulan. Menurut Nur Khasanah, ada saat di mana pemberian susu formula sebelum anak usia 6 bulan harus terpaksa diberikan itu di karenakan faktor kesehatan ibu yang saat itu sedang sakit, menderita penyakit tertentu seperti AIDS atau ibu meninggal dunia sewaktu ibu melahirkan. Namun tetap pemberian susu formula harus diberikan dengan tepat sesuai dengan usia bayi yaitu setelah 6 bulan. ${ }^{1}$ Dan hasil penelitian didapatkan sebanyak 30 responden (60\%) memberikan makanan tambahan pada usia $<6$ bulan dengan alasan agar anak lebih gemuk. Menurut Nur pada usia 4-6 bulan, bayi yang diberi susu formula mengalami kenaikan berat badan cenderung lebih cepat ketimbang diberi ASI, diperkirakan karena kelebihan air dan komposisi lemak tubuh yang berbeda dibandingkan ASI. ${ }^{1}$

Hasil pada penelitian disimpulkan bahwa sebanyak 46 responden (92\%) telah memberikan makanan lunak seperti bubur susu sebagai makanan tambahan pertama bayi usia $>6$ bulan. Makanan lunak sebagai makanan pertama bayi usia $>6$ bulan adalah makanan yang yang dimasak dengan banyak air, hal ini dikarenakan bayi mulai diperkenalkan untuk diberikan makanan tambahan pertamanya yang sesuai dan mempermudah proses pencernaan dari bayi.

Hasil penelitian menunjukkan 31 responden (62\%) tidak memberikan makanan tambahan seperti susu formula ketika masih memberikan ASI. Seperti yang diketahui bahwa jenis makanan tambahan ASI adalah seperti bubur susu dan nasi tim yang seharusnya di berikan bersama ketika masih memberikan ASI mulai dari usia diatas 6 bulan sampai usia 2 tahun dan lebih. ${ }^{8,10}$ Susu formula adalah alternatif terakhir bagi ibu, jika produksi ASI kurang/kondisi ibu yang tidak memungkinkan memberikan ASI karena menderita penyakit tertentu maka dengan terpaksa diberikanlah susu formula, namun jika susu formula diberikan bersama ketika masih memberikan ASI maka akan menimbulkan gangguan kesehatan pada bayi apalagi ketika bayi masih berusia $<6$ bulan. Bisa dikatakan susu formula adalah pengganti dari ASI.

Pemberian makanan tambahan 1-3 kali sehari pada bayi usia $>6$ bulan sebanyak 40 responden (80\%) telah memberikannya. Hal ini sesuai dengan yang dijelaskan dalam penelitian Bahri bahwa frekuensi pemberian pada bayi usia 6-8 bulan seharusnya adalah 1-2x/hari untuk makanan utama/pokok (makanan lunak, lembek, lumat) seperti bubur susu, nasi tim dan cemilan seperti biskuit adalah 1x/hari 
serta ASI yang dapat diberikan kapan saja. ${ }^{10}$ Kebanyakan 36 responden (72\%) memberikan susu formula sesaat setelah bayi lahir. Padahal menurut berbagai sumber dan Sri, dijelaskan bahwa sesaat setelah bayi lahir hendaknya segera diberikan kolostrum. Kolostrum adalah susu yang keluar pertama kali pada ASI berwarna kental kekuningan dan kaya akan antibodi. $^{9}$

Nur menjelaskan bahwa ada banyak ibu mengalami kesulitan ketika menyusui di hari pertama dan mengeluhkan ASI-nya tidak bisa keluar banyak (kurang) sehingga perlu ditambah cairan atau makanan lain, ini mungkin yang menjadi alasan mengapa susu formula diberikan sesaat setelah bayi lahir. Namun, ibu tidak perlu cemas karena di hari pertama, sebenarnya bayi belum memerlukan cairan yang begitu banyak sehingga tidak perlu diberikan cairan lain sebelum ASI keluar banyak yang kemudian nanti diberikan kepada bayinya. ${ }^{1}$ Menurut Ronald dikatakan bahwa untuk anak pertama, produksi ASI biasanya terjadi dalam 72-97 jam setelah persalinan bahkan ada yang lebih lama dari itu, namun untuk anak berikutnya ASI akan lebih cepat terbentuk. $^{8}$

\section{Hubungan Tingkat Pengetahuan Ibu melahirkan dengan Pemberian MP-ASI}

Berdasarkan hasil dari tabel 3 di atas maka hasil uji dari chi square di lihat dari Pearson Chi Square diperoleh nilai $p=$ $0,031(p<0,05)$ untuk perhitungan di atas. Dengan demikian bila dilihat dari hasil nilainya, maka dapat dikatakan secara statistik bahwa terdapat hubungan yang bermakna antara tingkat pengetahuan ibu melahirkan dengan pemberian MP-ASI.

\section{SIMPULAN}

Dilihat dari segi pendidikan yang kebanyakan adalah baik (SLTA) dapat dikatakan bahwa tidak ada hubungan dengan pengetahuan ibu meskipun dari hasil uji statistik diperoleh nilai yang bermakna yang menyatakan terdapat hubungan antara tingkat pengetahuan ibu melahirkan dengan pemberian MP-ASI. Hal tersebut dapat dilihat dari hasil penelitian bahwa kebanyakan ibu yang telah melahirkan (72\%) ternyata telah memberikan susu formula sesaat setelah lahir.

\section{SARAN}

\section{Bagi Ibu}

1. Menyarankan kepada ibu untuk memberikan air susu ibu (ASI) sesaat sesudah melahirkan sampai pada usia 6 bulan kemudian dilanjutkan dengan pemberian makanan tambahan yang tepat pada usia di atas 6 bulan pada bayi sesuai dengan tahapan tumbuh kembangnya.

2. Untuk mencegah resiko terjadinya penyakit seperti infeksi, diare, alergi dan malnutrsi bahkan obesitas maka ibu disarankan untuk tidak memberikan makanan atau cairan tambahan lain selain ASI sampai usia 6 bulan, guna menghindari berbagai resiko tersebut.

\section{Bagi Praktisi}

Diharapkan petugas kesehatan mendukung program Kesehatan Ibu dan Anak dengan mengadakan penyuluhan dan memberi pengarahan kepada ibu hamil saat antenatal care di poliklinik ataupun yang telah melahirkan yang dirawat di ruang nifas tentang pentingnya inisiasi menyusui dini sesaat setelah bayi lahir serta pemberian makanan pendamping ASI yang sesuai dengan usia tumbuh kembang bayi sampai pada resiko terhadap pemberian yang salah pada bayi.

\section{UCAPAN TERIMA KASIH}

Disampaikan sebesar - besarnya kepada penguji dr. Rudy A. Lengkong, SpOG-K dan Dr. dr. Joice Sondakh, SpOG$\mathrm{K}$ yang telah banyak memberikan saran, kritikan dan masukan kepada peneliti dan kepada seluruh staf bagian obstetri dan 
ginekologi yang telah banyak membantu dalam penelitian hingga terselesaikannya ini.

\section{DAFTAR PUSTAKA}

1. Khasanah N. ASI dan Manfaatnya. Dalam: Sawitri N, Editor. ASI atau Susu Formula Ya. Edisi 1. Jogjakarta: FlashBooks; 2011. p. 45-8; 155-218

2. Sri. Seminar ASI Ekslusif dan Aturan Hukumnya bagi Wanita Pekerja. [Online] 2006 February 23 [dikunjungi 2012 Sept 23]. Diakses dari : http://medicastore.com/seminar/1/Seminar _ASI_Ekslusif_dan_Aturan_Hukumnya_b agi_Wanita_Pekerja.html

3. Breastfeeding. [Online] 2012 September 22 [dikunjungi 2012 Sept 24]. Diakses dari: http://www.who.int/topics/ breastfeeding/en/

4. Yum J. The Effects of Breast Milk Versus Infant Formulae on Cognitive Development. Journal on Developmental Disabilities. 2007;13:135-7

5. Laporan Hasil Riset Kesehatan Dasar (RIKESDAS) 2007
6. Partiwi IGAN, Purnawati J. Kendala Pemberian ASI Ekslusif. [Online] 2009 [dikunjungi 2012 Sept 24]. Diakses dari : http://www.idai.or.id/asi/artikel.asp?q=20 1057102916

7. Basuki DN. Mengapa Menyusui Perlu di lindungi. [Online] 2009 [dikunjungi 2012 Sept 24]. Diakses dari: http://gizi.depkes.go.id/artikel/mengapamenyusui-perlu-dilindungi/

8. Sitorus RH. Pemberian Gizi untuk Bayi. Dalam: Aulia, Editor. Pedoman dan Perawatan Balita. Edisi 1. Bandung: CV Nuansa Aulia; 2011. p. 215-17

9. Adiningsih S. Gizi Bayi dan Balita. Dalam: Kusrianto A, Editor. Waspadai Gizi Balita Anda. Edisi 1. Jakarta: PT Elex Media Komputindo; 2010. p. 37-46

10. Bahri RM. Hubungan Pengetahuan Dan Sikap Ibu Dengan Pemberian MPASI Di Kelurahan PB. Selayang II Kecamatan Medan Selayang Tahun 2011[Skripsi]. Medan (SU): Fakultas Kedokteran USU; 2011.

11. Pedoman MP-ASI Lokal Departemen Kesehatan RI (2006). 